\title{
Opera in Prison: Impact of an artistic project on the reintegration of young people in prison
}

\author{
Cristóvão Margarido ${ }^{\dagger}$ \\ CICS.NOVA.IPLeiria, ESECS - \\ Politécnico de Leiria, Leiria - Portugal \\ rui.d.santos@ipleiria.pt
}

\author{
Rui Santos ${ }^{\dagger}$ \\ CICS.NOVA.IPLeiria, ESECS - \\ Politécnico de Leiria, Leiria - Portugal \\ cristovao.margarido@ipleiria.pt
}

\author{
Emanuel Margarido ${ }^{\dagger}$ \\ ESECS - Politécnico de Leiria, Leiria - \\ Portugal \\ emanuel.margarido@ipleiria.pt
}

\author{
Sandrina Milhano ${ }^{\dagger}$ \\ CIDEI; CICS.NOVA.Ipleiria, ESECS - \\ Politécnico de Leiria, Leiria - Portugal \\ sandrina.milhano@ipleiria.pt
}

\author{
Vanessa Póvoa ${ }^{\dagger}$ \\ ESECS - Politécnico de Leiria, Leiria - \\ Portugal \\ vanessa.povoa@ipleiria.pt
}

\begin{abstract}
The social intervention through the artistic languages can represent in the life of each subject a great socio-educational significance, contributing to reinforce numerous personal, social, affective, emotional and relational skills.

The social reintegration of young prisoners presents a great challenge for professionals, since the period of detention can indeed allow the individual a period of reflection, there are also ties (of friendship, family ...) that fall apart, and that, in most cases, it is important to reconcile.

The project "Opera in Prison" searched, through music, theater and dance to promote a strategy of socio-educational intervention that catalyzes a socially framed life. This project, funded by the Calouste Gulbenkian Foundation, took place in the Leiria Prison (youth), having been promoted by Sociedade Artística Musical dos Pousos (SAMP). Since the beginning of 2014, a group of 50 prisoners.

To understand the impact of this project on the process of social reintegration of young prisoners, a research methodology was adopted based on interviews with the various stakeholders in the project.

The results presented evidenced the role that artistic languages have played in the lives of young prisoners and their families and the way in which they have contributed to a more effective social reintegration.
\end{abstract}

\section{CCS CONCEPTS}

- Social and professional topics;

\section{KEYWORDS}

Artistic languages, Young prisoners, Social reintegration

Permission to make digital or hard copies of part or all of this work for personal or classroom use is granted without fee provided that copies are not made or distributed for profit or commercial advantage and that copies bear this notice and the full citation on the first page. Copyrights for third-party components of this work must be honored

For all other uses, contact the owner/author(s).

TEEM'20, October 21-23, 2020, Salamanca, Spain

(c) 2020 Copyright held by the owner/author(s).

ACM ISBN 978-1-4503-8850-4/20/10.

https://doi.org/10.1145/3434780.3436593

\section{ACM Reference Format:}

Cristóvão Margarido, Rui Santos, Emanuel Margarido, Sandrina Milhano, and Vanessa Póvoa. 2020. Opera in Prison: Impact of an artistic project on the reintegration of young people in prison. In Eighth International Conference on Technological Ecosystems for Enhancing Multiculturality (TEEM'20), October 21-23, 2020, Salamanca, Spain. ACM, New York, NY, USA, 6 pages. https: //doi.org/10.1145/3434780.3436593

\section{INTRODUCTION}

This work intends to make a first approximation in terms of impact evaluating of the project "Ópera na Prisão - D. Giovanni 1003Leporello 2015" developed by SAMP (Musical Artistic Society of Pousos), in the Prison Establishment of Leiria - Youth.

SAMP is a public utility institution, created in 1873. Since its foundation, SAMP has played a prominent role at the regional level, and, in some of its areas, at the national level, whether by the large number of professional artists who helped to form, either by the originality and quality of part of its programs.

In addition to the Philharmonic, a School of Arts with official teaching of Music, and various choral and instrumental formations, SAMP develops, in partnership with various State institutions and bodies, a wide range of programs in the fields of Training, Music Therapy and Expressive Therapies.

In 2014, SAMP, in partnership with the Prison Establishment of Leiria - Jovens (youth) ${ }^{1}$, implemented the project "Opera in Prison: D. Giovanni 1003 - Leporello 2015", a program in the scope of classical music, financed by the Gulbenkian Foundation through the Partis - program Social integration through artistic practices. The aim of this project was to develop the artistic creation process of an opera (Ópera Il dissoluto punito, ossia il Don Giovanni) with prisoners, with the aim of enhancing, through artistic creation in the field of music in general and opera in particular, the self-esteem, self-control and personal and civic training of prisoners in the Leiria Prison. Continuing this objective directed personally to each prisoner, to promote their social integration in the communities to

\footnotetext{
${ }^{1}$ The Leiria Prison (youth) is part of the Special Prison and is the only one in the country aimed at the prison treatment of young offenders who practice deviant behaviors. In this establishment, inmates, aged between sixteen and twenty-five years old, benefit from specialized education support, with the possibility of enjoying an educational component complementary to the school level they attended in freedom, they can also attend professional courses and participate in various social projects created by various external entities such as the "Ópera na Prisão" project.
} 
which they belong, involving local artistic structures. ${ }^{2}$ More and more social intervention projects appear, aiming to act through the arts (music, dance, theater, photography, etc.), with socially more vulnerable or disadvantaged groups.

In this context, music serves as a potentiating tool for change and transformation, as stated by Catarina Magno "Social intervention through art emerges as a response to social needs, that is, facing the various social problems, there is a need to create new forms of intervention, to promote social inclusion in order to foster citizenship" [15]

Following the implementation of the project, the various professionals involved felt the need to carry out an assessment that would allow them to reflect on the results achieved. Through the evaluation it is possible to recognize the most positive aspects of the intervention as well as possible errors to avoid in the future. As Gloria Serrano, we are also fully aware that "In the scope of Social Projects, little attention is paid to evaluation and, however, it is necessary to determine how, to what degree and to what extent the proposed objectives were achieved, to determine gaps and errors in achieving them, successes and unintended effects expected. This dimension is uncommon in Social Action projects [...] For this reason, it is convenient not to rely on memory and start planning the project's evaluation, making periodic and systematic records of all specific activities and conduct that arise during the execution of the project." [23]

The team responsible for the implementation of the project collected data on all the interventions carried out, however, the need was felt to resort to an external evaluation team that could work on these data and consequently present the results. Following this process, contacts were made with the Higher School of Education and Social Sciences of the Polytechnic of Leiria (ESECS-IPL), which through CICS.NOVA.IPLeiria - Interdisciplinary Center for Social Sciences from Nova University, agreed to carry out the external evaluation using its researchers.

This article is the result of a first approach by the team of researchers to the contexts and actors of the project, which is why some considerations arising from the first interviews with professionals, young prisoners and family members involved in the "Opera in Prison" project.

\section{METHODOLOGICAL PROCEDURES}

For this investigation, a qualitative approach was used. In this sense, this work, based on the basic assumption that the social world is a world built with meanings and symbols, which according to Moreira [19], implies the search and understanding, through which the subjects undertake significant actions. Thus, this methodology is essentially based on a discovery, understanding, interpretation and reflection of the study object, which encompasses different methods of collecting and analyzing information [1]. In this way, from the perspective and experiences of the actors involved in the process, it seeks to investigate the reality as the empirical data emerge [6].

\footnotetext{
${ }^{2}$ The presentation of SAMP and the project "Ópera na Prisão: D. Giovanni 1003 Leporello 2015" can be found on the SAMP website at the following email addresses: http://www.samp.pt/portal/?id=2152 and at http://www.samp.pt/portal/?id=2444
}

As instruments for data collection, documentary research was considered, a focus group interview with three facilitators of the SAMP project, two semi-structured interviews, one to an exprisoner, now on probation, and another to the family of a prisoner who participates in the project.

The documentary research allowed to frame the theme from a theoretical point of view and to analyze the documents related to the implementation of the project. Through the interviews, it was intended that each interviewee expressed his/her perception, interpretation and experience about the development of the project.

Regarding the procedures, the focus group took place at the SAMP facilities and the interview with the ex-prisoner and family members took place at the end of an activity held at the Calouste Gulbenkian Foundation, with the purpose of sharing some moments recorded on video and photography within the scope of the project. During the process, an environment of cooperation and involvement was created, with the participants establishing a close relationship with the researchers, expressing feelings and emotions.

After the full transcription of the interviews, the content analysis of the material collected, allowed us to understand the different perceptions about the "Opera in Prison" project.

\section{CONCLUSIVE ANALYSIS}

As stated by Vygotsky, in [2] "the need for creative expression as a way of representing the world and communicating is an integral part of human nature (...) it is universal" Art is a form of expression and interpersonal communication that has always been present in everyday human life. Rock engravings, for example, reflect precisely this artistic and communicative portrait of the population reality of Prehistory.

It is necessary to clarify that, when we integrate Artistic Expressions in a perspective of intervention in education and orientation, there is no need for us to be artists with technical training in the various means of expression, nor is our goal centered on the formation of artists. In that sense, when the intervention is sustained and integrated with Artistic Expressions, the primary objective should always be interpersonal training and the promotion of active participation, creativity and countless personal, social, educational and therapeutic skills. With regard to these skills, it is relevant to add that they are interconnected with the benefits that several authors attribute to the exercise of an intervention guided by the applicability of Artistic Expressions. For example, Arquimedes Santos argues that "Education through Art meets, above all, the formation of Personality" [22].

Regarding this matter, we can identify personal, social, educational and therapeutic benefits.

Regarding personal benefits, the development of expression, attention, confidence, sensitivity, imagination, knowledge, creativity and problem solving stand out $[5,20,25,26]$.

Concerning social benefits, several authors argue that they contribute to interaction, communication, negotiation, inclusion, relationship with the Other, teamwork and reality projection $[3,7,8,11,20,27,29]$.

Considering the educational benefits the Artistic Expressions contribute to the reduction of school dropout, presenting itself as a measure to reinforce academic success. In this sense, Cross [7] adds 
that people's contact with the arts helps to eradicate loitering and vandalism. However, Robinson [21] explains Artistic Expressions do not have the deserved prominence in school contexts, being seen in general terms as a complement to other subjects considered more relevant, which is why they are not given the interest and protagonism they should have. For Landier and Barret [12]"it is necessary to claim dramatic activities in school time, in programs and in official instructions. This is neither a marginal activity, nor a reward, nor a luxury, nor a pastime; it is a full-fledged, important, useful (albeit playful) and, moreover, enjoyable activity, which does not harm either work or effort".

Finally, referring to the therapeutic benefit, Alberto Sousa [25], argues that an education focused on immediate expressive objectives, contributes in a very significant way to the maintenance of a healthy mental life.

Thus, the diversity of benefits arising from Artistic Expressions in socio-educational intervention is remarkable, as well as their contribution to the development of intervention subjects, empowering them and providing them with opportunities to express themselves freely, expressing aspects that are intrinsic to them, and contributing, therefore, to reinforce innumerable competences, improving the knowledge of themselves and others, as well as to involve them in society.

The artistic-expressive spheres are vast, so when an intervention is defined based on these practices, it is urgent to select one or more specific areas. Therefore, for the project that was created and that will be presented later, OPERA was selected as the main artistic component.

Regarding the constraints that arise from the excessive valuation of the final result to the detriment of the creation process Cross [7] uses Spencer, a philosopher who perceived art as being a process, citing that "It is not a question of whether the child is producing good designs. It is a question of whether she is developing her faculties» [7]. In this way, also in the "Opera in Prison" project it is important to emphasize "creativity more than creation, man more than the artist, the citizen more than the specialist" [9]. In the same way, Barrett also meets this premise, revealing that "the quality and success of artistic work are of less importance than the decisions taken in the creative process" [28]. Therefore, it is important to take into account the consideration of Nóvoa, cited by Maria de São Pedro, that "(...) in education what makes the difference is the process, and not the product" [13].

In short, as argued by Fontanel-Brassart and Rouquet, referring to Art Education: "It will no longer be a question, therefore, of giving birth to artistic skills, but rather of taking care of the overall development of the individual and a self-conquering of his personality, leaving the manifestation of talents on a secondary level. Activity and experimentation, practiced individually or in groups, will be the essential (...)" [10].

We are, therefore, very close to what Sandrina Milhano says, when she states that: "There are several examples in which art, in this specific case music, was, and is still used to promote feelings of group and belonging, affinities, sharing of ideas, synchronization between people and groups, but also an important element of creation of a collective identity, encouraging social cohesion thus having the potential to become a mark of personal identity but also of a group." [18].

Thus, like Sandrina Milhano [17] we also consider that the complex and multifaceted interactions that exist between music, the individual, experiences, situations, and people can influence their development, not only musical, but also the development of their identities and social skills because "[...] Every human being endowed with musical sensitivity is aware of the magnetism that she exerts on things and people around her. Music acts in the sphere of feelings. It is one of the most important vehicles for man to express, introduce and externalize emotions. Therefore, it is not a mistake to say that the power of music in man is unique" (Fernandes (2008) in [24]).

For the team of facilitators of the project "Opera in Prison", composed of the people designated by "L", "D" and "R", SAMP has, in its genesis, a similar objective: "[...] arises from a man who sees art and music as a tool for social integration, for relieving what the problems of a violent society are" (L).

"P" is a former prisoner who experienced the Opera in Prison when he was in prison. Now, in freedom, he characterizes the way he received the invitation to integrate "Opera in Prison" as a shock, feeling in an unknown territory. The fact that he had knowledge and some monitoring of the project in a previous edition, with other prisoners, led him to put that feeling into perspective and to want to experience the proposed experience: "At first it was a shock [...]. I was not used to dealing with this, it is not our area. But yes, we had already experienced the first project of our colleagues, we liked to see it, and we wanted to try it" (P).

What initially moves the young prisoner to join the project are possible advantages in decisions about times of imprisonment. The project appears as a possible way to be able to have their precarious freedom earlier when collaborating on proposed initiatives. However, the experiences shared over time change the nature of the will and the motivations for mobilization become the experience of making art and spectacle: "At first we had that idea of going to the opera to get freedom faster, but we had to know that, we got to know it and in the end it was no longer because of the precariousness, it was more for the show, for the opera, we started to live the scene. In the end it was no longer to reach a goal, it was to make a show" (P).

One of the team members underlines the importance of the show, especially as a guiding purpose of the activities: Performance is very important because it is channeling there. It does not mean that there were not very important things. But it is very important $(\mathrm{R})$. For $\mathrm{L}$, the prison context would require more than music lessons: they would have to be artistic activities that stand out and with a different structure and dynamics from those usually adopted in a normal schooling course: "[...] they were not music lessons that could result there, if school is a bad thing out there, how can it be a good thing out there? So, they are inside because they are not part of the school outside, because the school does not solve their problem" (L).

The young prisoners' surprise regarding the choice of opera as a musical genre to support the project extends to their families, confirming a cultural differentiation that excludes musical types classifying and relating people and musical genres from the thoughtless construction of a normalization of compartmentalized assignments. Thus, the reactions of prisoners and their families are usually accompanied by astonishment or surprise: "[...] we were 
not counting on a kind of rap to change to an opera, and we were speechless, but we thought we were with him, we were fine" (cousin of $\mathrm{P}$ ).

As a musical genre, the choice of opera was precisely due to the breadth of artistic languages it presents, differentiating itself from other art forms by its scope: "[...] there is no more complete artistic language than opera. The opera is, as Wagner says, "a total work of art". Because there is dance, theater, music, scenography, visual arts, etc." (L). In the opinion of professionals, opera has differentiating characteristics both in this breadth of artistic forms and in the intensity of power that it conveys in an exclusive way: "[...] when they saw an opera (....) it has energizing! And then we started the project, we started taking musicians, working with prison guards, inside the establishment, involving theater and dance, [...] because opera has this particularity, why opera? although it seems to us that the screaming thing is very strange, but in fact that screaming thing is very powerful" (L).

Since the beginning of his participation, $(\mathrm{P})$ says that he feels noticeable changes in his life. This path of metamorphosis began by approaching musical instruments, by the emergence of new interpersonal relationships and, progressively, transforming learning with reaching the dimensions of thought and perceptions about the world. The development of the project reflected a significant impact on the inmates' reflexivity: "[...] we got to know the instruments, we met people, we were learning things, many things changed, our way of thinking, of seeing the world around us was changing !" (P).

The professionals report the importance of the intervention that was carried out beyond the context of the prison, since the results of the show are just the visible part of a complex work that has been done in several dimensions, in which the emergence of a trust relationship is makes the basis of the whole process and extrapolates the prison establishment. On the part of the team of professionals, the process of approaching young prisoners is carried out at various levels and rhythms: "[...] we bring classical language closer to the language of prisoners. We have been approaching for a year, getting to know each other personally and artistically. We took some artists and musicians there. We have 50\% of time inside the prison and 50\% outside it" (L).

In addition to working with inmates, an important part of the project is precisely the involvement of family members and other close people, in the context of origin: "We were on the ground with the prisoners every day, and we heard them talking about their relationship with the system, what was important to them, but then what is the big news about this project [...]? It is not the work inside the prison, it is the work outside the prison. They are mothers, girlfriends and brothers" (L).

This work of proximity and involvement in interpersonal relationships takes place over the first of the three years of the project's duration: "[...] this is it: getting to know each other, getting to know the mother, the father, where they live, what they do; who am I, who are you and what are we doing here; you and me; what brought you here, what brought me here. And what matters in the project is when they understand what we are doing. What changes in our lives is when we arrive at the prison with a photo of their room or when I arrive with a photo of the grandmother, or the neighbor" (L).

In a daily life deprived of freedom, whose main consequence is the lack of being with family members and the private forum, this type of intervention is received with admiration on the part of the prisoners: "We say, "- look, I was at your house with your mother", and none of them believe, and they reply" - then you go from here to Lisbon to meet my family? Looking for what? With what interest?" (D).

This work, of mediation carried out between the prison establishment and the contexts of origin, in which connections are made between prisoners and their family and personal networks, allows the prisoner to reflect his human value and reconfigure his place in the project team, giving it greater power in the intervention: "This is what power is, not Mozart. Mozart is a mediator, the power is this, this is the photograph. It is the thought that "- I exist as a person, to the point that someone goes to Amadora on purpose to sing congratulations on the night my mother turns"' (L).

The team of professionals understands that the intervention with and through families has a clearly motivating effect on prisoners: "From the moment we managed to reach their families, everyone changed" (D) In some cases, this intervention managed to bring together family ties that were severed: "[...] for example, the family and the prisoner have no connection, there is no acceptance, there is revolt, and after we enter the process, the family again believes in the child and another opportunity" (R).

In the second year of the project, the relationship with the team of professionals is built and consolidated, as well as the learning that precedes the performance of the shows. Young prisoners are aware of the importance given to the project by those responsible for the financing program and its projection in the media.

In the last year, prisoners are expected to apply their learning to facilitate a process of social reintegration in freedom. However, at this level, expectations are in contrast to realities, since the objectives of integrating prisoners in professional circles, established through protocols with dozens of host organizations with a view to continuing training under free regime, contain some impediments to difficult resolution: "But is there a prisoner, or mother of a prisoner who wants, when his son leaves prison, to be accepted into a company that only receives him because he is an ex-prisoner who has behaved well? Behaving well did not exist, he is an ex-prisoner. Nobody wants it!” (L)

Positive discrimination thus continues to be felt as a form of discrimination as prisoners seek, above all, to "erase" the past, operating a total disconnection, since "By his own will, consciously or unconsciously, the subject seeks the best form of adaptation and integration to the field he faces, normalizes, within what is considered the norm and outshines himself, within his psychic and corporeal possibilities, everything which may constitute an obstacle to the mirror of this normality. That part of you that leaves you in the dark will be less at risk of being perceived and thus moving away from the possibility of being called into question, discussed or denigrated." [16]

We are, therefore, in this case, situated within what Roger Bastide defines as the cutting principle ${ }^{3[4]}$ because the project "Opera in Prison" ends, in the case of this young prisoner, by being undoubtedly associated with a life experience that he does not want, from the moment it is free of the system, present in its future. In this sense also $(\mathrm{P})$ says that "[...] no prisoner wants to hear about the

\footnotetext{
${ }^{3}$ Coupure was the term, in French, used by Roger Bastide. It is possible to find this term translated and quoted in different ways by different authors. Cut, split, rupture, are some of the examples found during our bibliographic review.
} 
opera when he goes out [...], because as soon as the sentence ends' I want to forget everything that happened to me in this time, I want erase this from my life, and I want to have another world. And to have another world, none of this can be there" (P).

However, the young prisoner himself recognizes very positive aspects in the project and that can be used as a lever for a more effective social reintegration: "[...] our way of thinking and seeing things changes, we started to perceive things that had never crossed our minds, and we started to live things that we would never have lived had it not been for this opportunity, this experience. And they get us to think about the scenes, about everything, about art, about music, and open our horizons, knowledge a bit" (P).

(J) has been in prison for about 6 years without having yet been authorized for a precarious exit. The family's adherence, namely of its mother, to the participation in the project has been happening gradually. At first, there was an immediate refusal to attend a rehearsal, which relates to the characteristics of a musical genre that family members reject because they are unable to relate it to their personal tastes: "Look, the first time they called me to invite for an opera rehearsal I said I wasn't going" (J's mother).

This type of refusal is analyzed and, in some cases, the team understands the existence of other factors that hinder the presence of families in the project events and which are related to the daily work or some distance that they prefer to maintain: "[...] they cannot abandon their work and their life to come to a person they do not know or to whom they have been told a thousand times not to do crap" (D).

In the case of $(\mathrm{J})$ 's mother, the insistence of a second invitation was followed by greater consideration: on the one hand, the lack of interest in the project was maintained, but the advantage of being able to provide greater proximity to the child, in a context understood now as his "home", he led this mother to gradually join: "[...] and I said to my daughters 'I will, I will try, I may not like it, but I am at my son's house'. [...] In the project I managed to spend more time with him, more than visiting time" (J's mother).

"When $(P)$ joined the opera, my reaction was a laugh. I said to $(P)$ : "Ah, ah, ah, you at the opera? You must be kidding me, you're kidding! "But he said to me "- but you will also come, in a while they will call you" and I always thought it was just to see. But in the end, it was not just to see, it was to participate too. And I thought, "- me singing opera? Bad!" (P's sister).

From the first experiences and the enthusiasm felt in the constant calls for participation by the son, the mother of $(\mathrm{J})$ created the habit of being present in the project's initiatives and ended up developing the taste and interest in the project, which gained great meaning for the whole family involved: "[...] I picked up the pace and started going more often. My son always said: 'mom, mom, go, it's good for me' and I went, I started to go, and I liked it ... [...] the sister, the daughters ... ... came in ... ], I was happy, it is an activity that means a lot to them, and that means a lot to me"(J).

$(\mathrm{P})$ says that the project taught him how to sing opera, differentiating the specific skills needed to position his voice between this musical style and others he was used to: "I think this was the best because I learned a new style of music and I felt that pulled by our voice "(P). In his family, it is understood that "[...] he has a more open mind, he has more horizons, he has the ability to see things differently" (P's sister).
The project facilitators see several changes in the behavior of young prisoners: "[...] for example, a simple change in the way of dressing. Finding the person completely below and at the bottom and the next time we see the person, they have a different air, another attitude, with another posture" (R). In some cases, freedom itself becomes very difficult to face after the period of imprisonment: "Daniel, who was a very negative person, he was telling how he felt, what it was like to be at liberty, how he feels... [...] He says that the hard part is not being stuck, the hard part is when you come back out there "(D).

The least positive aspects that prisoners encountered throughout the project are mainly related to the conditions related to normal security and control by prison officials. Although the moments of development of the project provide spaces for family reunion, the circumstance of be prisoner remained, after all, unchanged and was evident in the exercise of the functions of the guards, in a way that contrasted with the desire to be with the family: "[...] the only thing I see negative is having the guards always on top of us, not letting us do anything, they did not let us be very close to the family" $(\mathrm{P})$

In terms of training habits, the path of $(\mathrm{J})$ was marked by successive breaks in school attendance before imprisonment. In the limitations that the lack of freedom provides in prisons, the activities developed by "Opera in Prison" contributed to promote differentiating experiences and personal and social transformation. The now the prisoner has completed compulsory education and projects to continue his studies in a future in freedom.

"Opera in Prison" project was felt as a challenge due to the characteristics of creativity and originality among its participants, who were motivated by the irreverence reflected in the act of expressing themselves artistically through opera in a prison context: "He liked this, and this activity it is something new for him, so he grasps this experience with strength"(J's mother).

The project facilitators managed to create an open and trusting relationship with the prisoners and their families. These facilitators, in addition to be an important family link during the period of imprisonment, became an important element of support in their personal networks, even after the prisoners have finished serving their prison terms:

"What is most transformative is to perceive the involvement of these individuals outside, around this table, we have prisoners who, when they left precarious, came here before going to their homes. And today I still receive, I will not say every day, but every week, I receive messages from mothers, from these boys' girlfriends asking me questions. Even today, these families, of the boys who have already left, have an attitude towards this project" (L).

On the other hand, adherence to this project allowed the establishment of close affective bonds with people of reference in the artistic world: " $(L),(R)$. and $(D)$ are like brothers to him. Sometimes he calls me saying " $L$ didn't call, $D$ didn't call, what are we going to do?" (mother of J). The professionals themselves encourage the maintenance of contacts with the purpose of making the bonds that are created last: "We spoke, exchanged personal contacts, messages for these two worlds to cross, and we have some cases" (D). For (L), there is an awareness of transformation that also operates in itself, feeling the effects of the intervention as a motivational factor: "[...] above all, and that is what moves me to be in this project, it is what we 
are we transform as people globally and professionals in this project "(L).

The "Opera in Prison" project allowed artistic creation, in a performative aspect in a dialectic "between the Self and the Other, in a close connection between acting and thinking. . . Active learning, in which the movement of bodies is synonymous with involvement in projects with senses, without chairs that imprison them" [14].

\section{REFERENCES}

[1] Amado, J. (2014). Manual de Investigação Qualitativa em Educação. Coimbra: Imprensa da Universidade de Coimbra.

[2] Bahia, S. (2009). Constrangimentos à Expressão Artística In Invisibilidades Revista Ibero-Americana de Pesquisa em Educação, Cultura e Artes, pp. 137-148. Porto: Rede Ibero-Americana de Educação Artística, p.139.

[3] Baldwin, P. \& John, R. (2012). Inspiring Writing Through Drama: Creative Approaches to Teaching Ages 7-16. London: Bloomsbury.

[4] Bastide, Roger (1955), "Le principe de Coupure et le Comportement AfroBrésilien", in AnaisXXXL Congresso Internacional de Americanistas, S. Paulo, Vol. I, pp 493-503.

[5] Bompastor, et al (2012). "Jogar com as emoções, encenar o futuro - Expressões dramáticas na prevenção da conduta em crianças. In Dalmann, E. \& Ferraz, M. (Coord.) (2012). Metodologias Expressivas na Comunidade, pp139-166. Lisboa: Tuttirèv Editorial Lda.

[6] Coutinho, C. P., (2013). Metodologias de Investigação em Ciências Sociais e Humanas: Teoria e Prática. ( $2^{\mathrm{a} e d}$.). Coimbra: Almedina.

[7] Cross, J. (1983). O Ensino de Arte nas Escolas. São Paulo: Cultrix: Editora da Universidade de São Paulo, p. 33.

[8] Cunha, M. J. (2013). Expressões Artísticas na Educação e Desenvolvimento do Homem Novo. In Atas do XII Congresso Internacional Galego-Português de Psicopedagogia (pp. 1089-1100). Braga: Universidade do Minho.

[9] Fontanel-Brassart, S. \& Rouquet, A. (1977). A Educação Artística na Acção Educativa. Coimbra: Livraria Almedina, p. 25.

[10] Fontanel-Brassart, S. \& Rouquet, A. (1977). A Educação Artística na Acção Educativa. Coimbra: Livraria Almedina, p. 24.

[11] Gallagher, K. (2000). Drama Education in the Lives of Girls: Imagining Possibilities. Toronto: University of Toronto Press.

[12] Landier, J. C. \& Barret, G. (1994). Expressão Dramática e Teatro. Porto: Edições Asa. p, 205.
[13] Lopes, M. S. P. (2011). O saber dramático a construção e a reflexão. Fundação Calouste Gulbenkian, p.84.

[14] Lopes, M. S. P. (2011). O saber dramático a construção e a reflexão. Fundação Calouste Gulbenkian, p.21.

[15] Magno, C. (2016). A música como estratégia de aumento da qualidade de vida de idosas institucionalizadas em lar residencial. (Dissertação de Mestrado não editada). Faculdade de Psicologia e Ciências da Educação e Faculdade de Economia da Universidade de Coimbra, Coimbra.

[16] Margarido, C. (2012) Trajectórias Pessoais e Identidades Profissionais de Assistentes sociais. Tese de doutoramento. Lisboa: UCP, p.93.

[17] Milhano, S. (2012). Music teachers and their pupils: musical activities, selfperceptions, and attitudes to music. EDULEARN12 International Association for Technology, Education and Development. Barcelona, Spain.

[18] Milhano, S. (2014). Práticas musicais e artísticas e a (re)construção de identidades numa comunidade sénior, In Fontes, A., Sousa, J., Lopes, M.S. P., Mónico, S. (Org.). Cultura e Participação: Animação Sociocultural em contextos Iberoamericanos, (pp. 223-233), Leiria, Rede Iberoamericana de Animação Sociocultural, ISBN: 978-98920-5122-2, p.226.

[19] Moreira, C. (2007). Teorias e Práticas de Investigação. Lisboa: Instituto Superior de Ciências Sociais e Políticas.

[20] Oliveira, M. \& Milhano, S. (org.). (2010). As Artes na Educação: Contextos de Aprendizagem promotores de Criatividade. Leiria: Folheto Edições e Design Centro de Investigação Identidades e Diversidades.

[21] Robinson, K. (2010). O Elemento. Porto: Porto Editora.

[22] Santos, A. (2000). "A Expressão - Novas perspetivas e implicações". In Cabral, A. (Org) (2000) Educação pela arte - Estudos em homenagem ao Dr Arquimedes da Silva Santos, pp. 75-87. Lisboa: Livros Horizonte, p.64

[23] Serrano, G. (2008). Elaboração de Projetos Sociais - Casos práticos. Coleção Educação e trabalho social, Porto: Porto editora

[24] Simões, E. (2014). Música: a linguagem intercultural na aprendizagem de ele. (Tese de Doutoramento não editada). Universidade de Trás-os-Montes e Alto Douro, Vila Real, p.26.

[25] Sousa, A. (2003). Educação pela Arte e Artes na Educação: $2^{\circ}$ Volume - Drama e Dança. Lisboa: Instituto Piaget.

[26] Vianna, T. \& Strazzacappa, M. (2001). Teatro na Educação: Reinventando Mundos. In Ferreira, S. (org.). (2001). O Ensino das Artes: Construindo Caminhos (pp. 115-138). São Paulo: Papirus Editora.

[27] Wagner, B. (1998). Educational Drama and Language Arts: What Research Shows. Chicago, Illinois: Heinemann.

[28] Barrett, M. (1979). Educação em Arte. Lisboa: Editorial Presença.

[29] Costa, I. (2003). O Desejo de Teatro - O Instinto do fogo Teatral como Dado Antropológico. Lisboa: Fundação Calouste Gulbenkian - Fundação para a Ciência e Tecnologia, p.121. 